\title{
Chapter 19
}

\section{'Las Empoderadas' Women Coca Growers Building Territorial Peace}

\author{
Ingrid Marcela Muñoz Quesada
}

Translated by Chiara Marinelli

'I am no longer accepting the things I cannot change. I am changing the things I cannot accept'.

- Angela Y. Davis

Lili is a campesina woman in her 40s. For 20 years, she has lived in Putumayo, one of Colombia's principal regions of coca cultivation in the AndeanAmazonian area bordering Ecuador. She is a smiling and tough woman who has affectionately earned the title of la madre de todos (the mother of all). A victim of the armed conflict, she has lost two of her children in the context of the war. Today, she is one of the most important social leaders working in defence of the territory, human rights and the substitution of coca cultivation established in the Final Peace Agreement signed between the Colombian State and the former Revolutionary Armed Forces of Colombia - People's Army (Fuerzas Armadas Revolucionarias de Colombia - Ejército del Pueblo, FARC-EP). Like her, thousands of peasant women have demanded recognition of the peasant women's contribution to the development of territories forgotten by the State but built by their communities' hard work.

In Colombia, coca leaf production has a woman's face. Women do not just take care of homes but they are also day labourers or gatherers, farmers, cookers and other tasks related to coca cultivation. This phenomenon in which a great percentage of women are responsible not only for the crops but also for the coca grower households has a basic explanation: coca cultivation takes place within the context of the armed conflict, a war in which many women were widowed.

\footnotetext{
The Impact of Global Drug Policy on Women: Shifting the Needle, 179-181 Copyright $\odot 2021$ by Ingrid Marcela Muñoz Quesada These works are published under the Creative Commons Attribution (CC BY 4.0) licence. Anyone may reproduce, distribute, translate and create derivative works of these works (for both commercial and non-commercial purposes), subject to full attribution to the original publication and authors. The full terms of this licence may be seen at http://creativecommons.org/licences/by/4.0/legalcode doi:10.1108/978-1-83982-882-920200024
} 
So, in the most inhospitable corners of the country, women have assumed the challenge of the social reconstruction of their communities. Hence, any proposal to overcome the scourge of drugs in Colombia must contemplate the 'gender approach,' as indicated by the Final Peace Agreement, recognising the important role that women have played in the development of the regions.

Maria is 54 years old and was born in the Department of Caqueta but has lived for more than 20 years on the banks of a beautiful river in the Department of Meta. With a black complexion and a strong voice of almost musical laughter, she is cheerful despite having a difficult life history. She tells her story with her eyes, almost as if awaking her past, about how a paramilitary raid in 1998 left her without a father, without a husband and without two of her brothers. She remembers how the women of her house (her mother, her two sisters and herself) dried their tears of loss and tended to their small cocoa and banana farm. They sold the cocoa for very few pesos and when confronted with the difficult situation in which they lived, they began to grow coca. It was the only crop that enabled them to cover household expenses for their seven young children.

She tells of how the four women of the house undertook all cultivation-related activities. They obtained coca seeds at a time people said it was the most profitable. They sowed and tended the crop. She states that for the farmer, it is more profitable because many times the buyer comes to the door of the farm to buy the coca paste. If they sow another agricultural product such as banana, they would have to pay the transportation by river and land until they reach the nearest village, without guarantee that the banana can be sold at a fair price. She says that they do not grow coca to harm humanity but because the State has never looked at the peasants as citizens, but as criminals. She adds:

If the Colombian state invests in the countryside and in peasant production many things would change. The Final Peace Agreement must be fulfilled. In point 4 , it talks about replacing coca not only by replacing it with other crops but by guaranteeing the ownership of the land, health, education and routes to commercialize our products. If these are not fulfilled, people are going to grow coca again and this will be a never-ending story.

They insist that behind every hectare of coca cultivated there are women and men trying to overcome difficult conditions of poverty and exclusion. In the framework of the National Comprehensive Program for the Substitution of Illicit Crops (Programa de Sustitución Integral de Cultivos Ilícitos - PNIS) created by the Final Peace Agreement, tens of thousands of families have voluntarily eradicated their crops as a sign of their willingness to overcome the illicit production of coca. Once again they have placed their confidence in the Colombian state to move towards other productive models and guarantee rights and public goods in the territories of coca production.

Thousands of Colombian peasant women plough the land and are dedicated to educating those who will inherit the land. They believe that the Final Peace Agreement is a window of opportunity to generate territorial development. 
These women promote the empowerment of other women and they are organised in a concerted manner not only for the substitution of crops considered illicit but also to defend the territories from other extractive economies. The panorama has been very difficult. Those who lead these processes are being persecuted, threatened and killed. Within this group, there are also Afro-Colombian women, indigenous women and women belonging to the LGBTI population.

However, the social movement of peasant women is still vibrant. These women are the ones that build the country. In a Colombia that continues to dispute the concepts of war and peace, they are raising their voice to say that they do not want to continue giving birth to children to fight in civil conflict, that they are willing to contribute to the construction of a viable country for all its citizens. They are leaders but they are also mothers, daughters, cousins, neighbours, and friends. They insist that peace will not be possible without taking into consideration the women of rural Colombia, that Colombia has the potential to be a pantry of agricultural products and a development pole of the country.

Many are the stories of courageous women coca growers. They recognise that coca production in Colombia is an enclave economy. Many of them have made their way in the social struggles led mainly by men, to become protagonists of the peacebuilding process. Here they are, 'las empoderadas', the empowered, those who wake up every morning to work for a country of peace and social justice. 